\title{
Pemberdayaan penyandang disabilitas melalui community development KSM batik percik
}

\author{
Shindi Yana Desi Rahma Sari, Rizza Megasari* \\ Universitas Negeri Malang, Jl. Semarang No. 5 Malang, Jawa Timur, Indonesia \\ *Penulis korespondensi, Surel: rizza.megasari.fe@um.ac.id
}

Paper received: 6-8-2021; revised: 20-8-2021; accepted: 28-8-2021

\begin{abstract}
The existence of Persons with Disabilities with Diversity of Deafness and Mental Limitations is still often regarded as weak, helpless, unable to work and can even be said to be troublesome for others. With this assumption, a negative assessment emerges which causes some people with disabilities to feel inferior and lack self-confidence. When in fact they have skills that if developed will have a positive impact on them, for example to meet their needs. One of the efforts to improve the economic welfare of persons with disabilities is empowerment through community development of Batik Percik KSM. With this KSM, it will help people with disabilities to meet their daily needs. Persons with disabilities at this KSM will be given special training to create a product, namely batik percik. In the batik training, people with disabilities will be guided by the assistants at the Harapan Makmur KSM.
\end{abstract}

Keywords: empowerment; persons with disabilities; community development; non-governmental organizations (KSM); economic welfare

\begin{abstract}
Abstrak
Keberadaan Penyandang Disabilitas dengan Ragam Tuna Rungu dan Keterbatasan mental ini masih sering dianggap sebagai kaum yang lemah, tidak berdaya, tidak bisa bekerja bahkan bisa hanya dikatakan menyusahkan orang lain. Dengan adanya anggapan tersebut muncul penilaian negatif yang mengakibatkan sebagian penyandang disabilitas ini merasa minder dan kurang percaya diri. Padahal sebenarnya mereka mempunyai keterampilan yang jika dikembangkan akan memberikan dampak yang positif bagi mereka misalnya untuk memenuhi kebutuhan hidupnya. Salah satu upaya untuk meningkatkan kesejahteraan ekonomi penyandang disabilitas ini adalah pemberdayaan melalui community development KSM batik percik. Dengan adanya KSM ini akan sedikit membantu penyandang disabilitas tersebut untuk memenuhi kebutuhan hidupnya. Penyandang disabilitas pada KSM ini akan diberikan pelatihan secara khusus untuk menciptakan sebuah produk yakni batik percik. Dalam pelatihan membatik penyandang disabilitas akan dibimbing oleh para pendamping di KSM Harapan Makmur tersebut.
\end{abstract}

Kata kunci: pemberdayaan; penyandang disabilitas; community development; kelompok swadaya masyarakat (KSM); kesejahteraan ekonomi

\section{Pendahuluan}

Di indonesia keberadaan penyandang disabilitas masih sering dianggap sebagai kaum yang lemah, tidak berdaya, atau tidak bisa bekerja, dan bahkan bisa hanya dikatakan menyusahkan orang lain Penyandang disabilitas seharusnya memperoleh kesempatan yang sama untuk mengembangkan dirinya kemandirian sebagai manusia yang bermartabat. Sesuai dengan undang undang tersebut, penyandang disabilitas adalah setiap orang yang mengalami keterbatasan fisik, intelektual, mental, dan sensorik yang jika berinteraksi dengan lingkungan dapat mengalami hambatan dan kesulitan untuk berpartisipasi secara penuh dan efektif dengan warga lainnya. Ragam penyandang ini meliputi penyandang disabilitas fisik, intelektual, mental, maupun sensorik. (infodatin pusat data dan informasi kementerian kesehatan RI, 26 Januari 2021). Selain itu Komnas HAM dan Kementerian Sosial Republik 
Indonesia memandang bahwa istilah tersebut memiliki makna yang bernilai negatif dan tidak sejalan dengan prinsip utama hak asasi manusia sekaligus bertentangan dengan nilai-nilai luhur bangsa yang menjunjung tinggi harkat dan martabat manusia. Penilaian yang negatif ini mengakibatkan sebagian penyandang dissabilitas merasa minder dan kurang percaya diri, mengurung diri di rumah, tertekan secara psikologis, kurang bersosialisasi, dan tidak mau mengembangkan potensi dirinya. Padahal perlu diketahui penyandang dissabilitas memiliki kemampuan sama dengan orang non-disabilitas jika mereka diberdayakan secara maksimal.

Pada saat ini penyandang disabilitas masih menghadapi persoalan yang berkaitan dengan penghidupan dan kesejahteraan mereka (Surwanti Arni, 2014:41). Berbagai usaha pemberdayaan terhadap penyandang disabilitas telah dilaksanakan oleh pemerintah. Hal ini terlihat dengan telah terbitnya berbagai peraturan perundang undangan seperti menerbitkan Undang-Undang Nomor 4 Tahun 1997 tentang Penyandang disabilitas. Salah satu upaya atau peran yang dilakukan untuk meningkatkan kesejahteraan ekonomi adalah dengan adanya pemberdayaan masyarakat disabilitas melalui kegiatan usaha kecil dan menengah atau sering disebut dengan KSM (Kelompok Swadaya Masyarakat). KSM itu sendiri adalah sekumpulan orang yang menyatukan diri dalam usaha usaha di bidang sosial ekonomi untuk meningkatkan taraf hidup masyarakat. KSM dibangun dengan motif solidaritas yang berkomitmen untuk pengembangan sosial ekonomi dengan pendekatan komunitas (Community Development). Pendekatan komunitas (Community Development) adalah kegiatan pengembangan masyarakat secara sistematis, terencana, dan diarahkan untuk memperbesar akses masyarakat guna mencapai kondisi sosial, ekonomi, dan kualitas kehidupan yang lebih baik (Triyono 2014:116 dalam, Rahman 2009:108).

KSM batik percik atau ciprat dengan pendekatan komunitas ini menjadi salah satu peran usaha pemberdayaan yang dilakukan oleh desa setempat, hal ini dilakukan untuk meningkatkan kesejahteraan ekonomi khususnya penyandang disabilitas Hal ini didasari oleh jumlah penyandang disabilitas di desa Soso yang jumlahnya lumayan banyak sekitar 15 orang dengan berbagai ragam meliputi disabilitas tuna rungu dan keterbatas mental atau down syndrom, hal ini membuat aparat Desa Soso mempunyai ide berupa pembentukan sebuah program yakni pemberdayaan penyandang disabilitas melalui suatu wadah berupa KSM Harapan Makmur. Pada KSM ini Pemberdayaan disabilitas intelektual dengan ragam disabilitas tuna rungu dan keterbatasan mental akan diberikan pelatihan membuat sebuah karya yakni batik percik sebagai salah satu cara untuk meningkatkan kesejahteraan ekonominya. Oleh karena itu, pemberdayaan melalui kegiatan pelatihan batik percik di KSM ini dijadikan salah satu solusi untuk meningkatkan kesejahteraan ekonominya. Salah satu alasan memilih ksm batik percik ini untuk dijadikan penelitian karena pada ksm batik percik ini masih banyak kondisi sosial ekonomi bagi penyandang disabilitas khususnya disabilitas tuna rungu dan keterbatasan mental yang kurang terpenuhi dan hal ini berpengaruh terhadap kesejahteraan ekonominya, sehingga dengan adanya pemberdayaan melalui ksm batik percik ini menjadikan salah satu upaya untuk meningkatkan kesejahteraan ekonominya.

\section{Metode}

Pada penelitian kali ini peneliti menggunakan metode penelitian kualitatif. Yang mana penelitian kualitatif dimaksudkan untuk memahami fenomena tentang apa yang dialami oleh subjek penelitian misalnya perilaku, tindakan, secara holistik dengan cara deskripsi dalam bentuk kata kata dan bahasa secara alamiah dan dengan memanfaatkan berbagai metode alamiah. Jenis Penelitian yang digunakan dalam penelitian ini adalah penelitian deskriptif, yang 
mana penelitian untuk mendeskripsikan suatu gejala, peristiwa, dan kejadian yang terjadi saat ini. Peneliti berusaha mencari tahu serta menganalisis peran upaya pemberdayaan kelompok dissabilitas untuk meningkatkan kesejahteraan ekonomi melalui kegiatan KSM batik percik di Desa Soso Gandusari Blitar.

\section{Hasil dan Pembahasan}

\subsection{Perkembangan Usaha KSM Batik Percik Harapan Makmur}

KSM Harapan Makmur dibentuk berdasarkan adanya program dari desa. Program dari desa tersebut diperuntukkan kepada penyandang disabilitas yang cukup banyak sekitar 15 orang dengan ragam disabilitas tuna rungu dan keterbatasan mental, maka pemberdayaan untuk penyandang disabilitas dalam menciptakan sebuah produk akan sangat memberikan dampak yang positif bagi mereka misalnya dalam memenuhi kebutuhan hidupnya. Terbentuknya program desa dalam bentuk KSM ini awalnya dibina langsung oleh Carik Desa Soso atas persetujuan Kepala Desa Soso tersebut, dalam kegiatan pemberdayaan penyandang disabilitas tuna rungu dan keterbatasan mental ini diberikan pelatihan khusus untuk membuat sebuah produk yakni batik percik. Dalam kegiatan pelatihan membatik ini akan dibimbing oleh pengelola di KSM tersebut, memang butuh kesabaran dan ketlatenan untuk membimbing penyandang disabilitas ini. Salah satu upaya pemberdayaan masyarakat disabilitas melalui pelatihan keterampilan dapat mengembangkan potensi yang mereka miliki dan dengan begitu masyarakat akan terdorong untuk meningkatkan kemampuan dan keterampilan sebagai bekal untuk menciptakan kemandirian sehingga dapat meningkatkan kesejahteraan ekonominya (Ananda Shalsabila 2019:224).

Dalam perkembangan sebuah usaha tidak lepas dengan faktor faktor yang mempengaruhinya, beberapa faktor yang mempengaruhi antara lain modal, proses produksi, cara pemasaran dan tenaga kerja. Begitu juga dengan perkembangan usaha KSM Harapan Makmur ini juga tidak lepas dengan faktor faktor atau aspek tersebut, berikut beberapa faktor yang mempengaruhi perkembangan usaha di KSM Harapan Makmur:

\subsubsection{Modal}

Pada KSM Harapan Makmur ini modal merupakan faktor terpenting ketika akan membuat sebuah produksi. Pada awal produksi tentu membutuhkan modal awal, sedangkan di KSM Harapan Makmur ini sendiri modal awal yang digunakan berasal dari desa yang kemudian dengan modal awal tersebut para pengelola akan menggunakannya dengan sebaik mungkin. Hal ini sudah termasuk untuk membeli peralatan membatik serta bahan yang digunakan untuk membatik. Sehingga sampai saat ini modal yang digunakan berasal dari modal awal tersebut, jika modal tidak mencukupi maka dari pengelola harus benar benar mengalokasikan bagaimana dengan modal awal sekian bisa memenuhi kebutuhan yang digunakan untuk membatik, hal ini untuk mengantisipasi agar nantinya tidak mengalami kemacetan. Jadi harapannya dari pengelola itu dengan adanya keuntungan dari hasil penjualan ini bisa sedikit membantu bagi penyandang disabilitas dalam memenuhi kebutuhan hidupnya, sehingga jika semakin banyak modal yang dibutuhkan maka keuntungan yang diperoleh juga akan banyak. Faktor yang paling penting untuk perkembangan usaha dalam meningkatkan kesejahteraan ekonominya adalah modal. Modal merupakan kebutuhan yang komplekskarena 
berhubungan dengan keputusan pengeluaran dalam kegiatan usaha dalam meningkatkan pendapatan dan mencapai keuntungan yang maksimum (Priyandika, 2015).

\subsubsection{Proses Produksi}

Kemudian jika dilihat dari aspek proses produksi suatu barang, bahan baku menjadikan faktor utama ketika akan membuat batik percik. Bahan baku yang dipilih untuk digunakan membatik ini benar benar yang memiliki kuatitas bagus karena dengan bahan baku yang memiliki kualitas bagus pada hasil produksi batik percik juga akan terlihat bagus. Bahan baku yang digunakan untuk memproduksi ini harus sesuai dan diperhatikan karena jika bahan yang digunakan tidak sesuai maka akan berpengaruh terhadap hasil yang didapat, dari sinilah nanti akan berpengaruh juga terhadap laku tidaknya batik tersebut. Jadi dalam pemilihan bahan baku yang akan digunakan untuk membatik harus benar diperhatikan agar berpengaruh terhadap hasil akhir produksi batik percik tersebut. Dalam melakukan proses membatik ini juga tergantung cuaca pada saat itu ketika cuaca mendukung bisa memproduksi batik yang banyak tetapi jika cuaca tidak mendukung maka juga tidak bisa melakukan produksi batik. bahan baku dalam proses produksi sangat penting untuk dikendalikan dengan baik, sehingga perusahaan dapat menghasilkan pendapatan yang optimal (Siswanta, 2011).

\subsubsection{Pemasaran}

Cara pemasaran disini menjadi salah satu patokan keberhasilan suatu usaha tersebut, jika pemasarannya dilakukan tepat sasaran bisa dikatakan usaha tersebut berhasil. Pada KSM Harapan Makmur ini pemasarannya dilakukan dengan cara promosi lewat online dan offline, selain dari web sendiri para pengelola juga serta ikut mempromosikan lewat sosmed yang dimiliki seperti WA, FB, IG sedangkan offline dengan cara omongan satu ke omongan yang lainnya sehingga hal ini membuat banyak orang tahu produk batik percik. Semakin sering melakukan promosi maka juga banyak juga produk yang bisa dijual sehingga juga bisa mendapat keuntungan yang banyak pula. Pada era yang digital ini KSM Harapan makmur dalam melakukan proses pemasaran lebih sering dilakukan lewat online hal ini disebabkan karena pangsa pasar lebih banyak online. Oleh karena itu hal ini sedikit bisa membantu untuk memenuhi kebutuhan mereka. Proses pemasaran ini sangat berpengaruh terhadap keberhasilan suatu usaha produksi tersebut (Assuri, 2009:41).

\subsubsection{Tenaga Kerja}

Selanjutnya aspek yang mempengaruhi perkembangan sebuah usaha adalah tenaga kerja. Tanaga kerja juga sangat dibutuhkan dalam sebuah proses produksi, jika tidak ada tenaga kerja maka juga tidak bisa membuat produk., dalam KSM Harapan Makmur ini yang menjadi tenaga kerja adalah penyandang disabilitas itu sendiri dan para pendamping KSM Harapan Makmur tersebut. Para penyandang disabilitas diberikan pelatihan khusus untuk membatik yang mana nantinya akan dapat mengahasilkan sebuah produk dan mereka mendapat keuntungan dari hasil produksi nya. Para penyandang disabilitas pun disini merasa senang dengan adanya KSM ini, karena menurut mereka hal ini bisa sedikit membantu kebutuhan hidupnya. Tenaga kerja disini merupakan salah satu faktor yang sangat penting dalam setiap produksi perkembangan usaha, tanpa adanya tenaga kerja maka faktor produksi tidak akan berarti. Dengan meningkatnya tenaga kerja maka akan mendorong peningkatan 
produksi dan pendapatan pun juga meningkat sehingga dapat meningkatkan kesejahteraan ekonominya (Nayaka dalam Sumarsono, 2013).

\subsection{Peran KSM Harapan Makmur untuk Kesejahteraan Ekonomi Masyarakat Disabilitas}

Adanya peran KSM Harapan Makmur ini banyak memberikan dampak yang positif bagi penyandang disabilitas untuk meningkatkan kesejahteraan ekonominya. Terdapat beberapa peran KSM Harapan Makmur untuk meningkatkan kesejahteraan ekonominya. Berikut beberapa peran KSM Harapan Makmur untuk meningkatkan kesejahteraan ekonomi:

\subsubsection{Wadah Aspirasi}

Melalui wadah aspirasi mereka mendapat pengalaman banyak dan lebih bisa mengasah keterampilannya dalam membuat batik percik, mereka sangat berantusias dalam membatik. Selain itu dengan adanya partisipasi dari mereka dalam kegiatan produksi batik tersebut diharapkan dapat mengembangan penyandang untuk meningkatkan taraf hidupnya. Penyandang disabilitas tuna rungu dan keterbatasan mental ini bebas untuk menyalurkan aspirasinya dalam membatik. Salah satu peran KSM adalah sebagai Wadah aspirasi yang mana melalui partisipasi masyarakat dalam sebuah kegiatan mampu meningkatkan taraf hidup kebutuhan mereka. Melalui partisipasi masyarakat dalam hal ini dapat berupa gagasan dalam program tersebut serta keikutsertaan masyarakat dalam pelaksanaan program yang telah ditetapkan berupa tenaga, uang dan bahan (Ma'ruf Mu'min, 2011).

\subsubsection{Penyerapan Tenaga Kerja}

Dengan adanya KSM Harapan Makmur ini membuat penyandang disabilitas di desa soso merasa memiliki pekerjaan mempunyai kesibukan untuk membuat batik percik tersebut. Mereka diberikan pelatihan khusus untuk membuat sebuah hasil karya yakni batik percik, hal ini dilakukan agar mereka tidak menganggur dirumah sehingga bisa berpenghasilan sendiri. KSM juga memiliki peran sebagai penyerapan tenaga kerja, dengan adanya penyerapan tenaga kerja maka akan sedikit mengurangi tingkat pengangguran bagi mereka. Sehingga hal ini bisa membantu untuk memenuhi kebutuhan hidupnya (Ma'ruf Mu'min, 2011).

\subsubsection{Sumber Ekonomi/ Pendapatan}

KSM Harapan Makmur ini juga berperan sebagai sumber ekonomi atau pendapatan tersendiri bagi penyandang disabilitas di desa soso ini, dengan mengikuti pelatihan atau bergabung dengan KSM ini mereka bisa mendapatkan keuntungan sendiri dari hasil kerja kerasnya membuat produk batik percik tersebut. Mereka sedikit terbantu untuk memenuhi kebutuhan hidupnya sehingga tidak terlalu memberatkan kedua orang tuanya. KSM berupaya mendorong kegiatan usaha anggota dalam mewujudkan pembangunan ekonominya untuk meningkatkan kesejahteraan dan kemakmuran masyarakat. Dana yang didapat biasanya bersumber dari donatur maupun iuran anggota sendiri untuk kepentingan bersama (Ma'ruf Mu'min, 2011).

\section{Simpulan}

Dengan adanya pendekatan community development melalui KSM Harapan Makmur ini banyak memberikan dampak positif salah satunya adalah untuk meningkatkan kesejahteraan 
ekonomi. Kesejahteraan ekonomi itu sendiri dilihat ketika kondisi terpenuhinya baik kebutuhan material, spiritual sosial dan ekonomi warga negara dapat layak dan mampu mengembangkan dirinya sehingga dapat memenuhi kebutuhan hidupnya (James dan medgley dalam Huda, 2013). Kesejahteraan sosial ekonomi yang dimaksud disini adalah sejahtera sosial ekonomi bagi penyandang disabilitas. Selain itu perubahan yang terlihat ketika sebelum dan sesudah adanya pemberdayaan ini akan memberikan dampak tersendiri bagi penyandang disabilitas tersebut. Sebelum adanya pemberdayaan ini penyandang disabilitas menganggur, hal ini dikarenakan kurangnya rasa percaya diri yang mengakibatkan mereka minder dengan masyarakat lain sehingga motivasi untuk bekerja itu sangat rendah. Namun ketika sudah adanya pemberdayaan ini membuat mereka mengalami perubahan. Perubahan ini terlihat dari motivasi penyandang disabilitas untuk bekerja dan melatih keterampilannya untuk membuat batik percik dan ini menjadi solusi untuk meningkatkan perekonomiannya. Melihat hal ini maka dengan diberikannya pelatihan membatik yang diterapkan bagi penyandang disabilitas merupakan salah satu upaya pemberdayaan untuk meningkatkan kesejahteraan ekonominya (Sulistiyani, 2014:224).

Selain itu dalam Perkembangan KSM Harapan Makmur ini terdapat beberapa faktor yang mempengaruhinya antara lain modal, proses produksi, pemasaran, dan tenaga kerja. Modal awal yang digunakan di KSM ini berasal dari dana desa yang kemudian para pengelola akan mengalokasikan dana tersebut untuk membeli kebutuhan dan peralatan untuk membatik. Dalam proses produksi bahan baku yang digunakan harus benar benar diprhatikan kualitasnya, jika kualitasnya kurang bagus maka akan berpengaruh terhadap hasil akhir batik tersebut, dan selama proses produksi batik juga ditentukan dengan kondisi cuaca pada saat itu jika kondisi cuaca kurang memungkinkan maka tidak bisa memproduksi batik dalam jumlah banyak tetapi jika cuaca mendukung maka juga bisa memproduksi batik dalam jumlah banyak. Selanjutnya pemasaran, keberhasilan suatu usaha jika pemasarannya dilaukan sesuai dengan sasaran semakin banyak melalkukan pemasaran maka akan semakin banyak juga produk yang terjual, dalam KSM ini pemasaran dilakukan secara online dan offline tetapi di era globalisasi ini lebih sering melakukan pemasaran online karena pangsa pasar lebih banyak di online. Selanjutnya tenaga kerja, pada KSM ini tenaga kerja adalah penyandang disabilitas tuna rungu dan keterbatasan mental di desa tersebut dan pengelola ksm tersebut.

Disisi lain peran KSM Harapan Makmur disini juga dapat memberikan dampak yang positif bagi penyandang disabilitas ini. Beberapa peran KSM Harapan Makmur ini aalah wadah aspirasi, penyerapan tenaga kerja dan sumber ekonomi/pendapatan.

\section{Daftar Rujukan}

Ananda, S. (2020). Pemberdayaan Penyandang Disabilitas Melalui Pelatihan Pembuatan Boneka Bantal untuk Anak Down Syndrome di Desa Panciro. In the Indonesian Conference on Disability Studies and Inclusive Education (Vol. 1, pp. 217-240).

Bambang Ismawan, (2020). Pengertian KSM (online). Dari https://www.masterplandesa.com/kongreskebudayaan-desa/kelompok-swadaya-masyarakat-ksm-dalam-gerakan-revitlisasi-desa/. Diakses (29 November 2020).

Erlin Sudarwati, (2016). Artikel Penyandang Disabilitas (online). Dari https://www.kemhan.go.id/pusrehab/2016/11/24/artikel-kebijakan-penyandangdissabilitas.html\#. Diakses (23 Januari 2021)

H Ma'ruf Mu'min, (2020). Peran KSM (online). Dari http://eprints.ipdn.ac.id/2416/1/PERANAN\%20KSM.pdf. Diakses (30 November 2020). 
Infodatin, (2018). Pusat Data dan Informasi kementerian Kesehatan RI Dissabilitas (online). Dari https://www.kemkes.go.id/download.php?file=download/pusdatin/infodatin/infodatindissabilitas.pdf. Diakses (22 Januari 2021)

Mulyati, T., Rohmatiah, A., \& Lukito, M. (2019). Pemberdayaan Penyandang Disabilitas Dalam Mewujudkan Kemandirian Ekonomi (Kasus Di Desa Simbatan, Nguntoronadi, Magetan). Jurnal daya-mas, 4(2), 5760.

Murti, I. A. K. (2020). Makna kesejahteraan sosial ekonomi bagi para penyandang disabilitas di desa cibuyur, kecamatan warungpring kabupaten pemalang (Doctoral dissertation, Universitas Negeri Semarang).

Nayaka, K. W., \& Kartika, I. N. (2018). Pengaurh Modal, Tenaga Kerja dan Bahan Baku terhadap Pendapatan Pengusaha Industri Sanggah di Kecamatan Mengwi. Jurnal Ekonomi dan Bisnis Universitas Udayana, $7(8), 1927-1956$.

Nurjundini, N. (2020). Analisis peran usaha kerajinan batik tulis dan batik cap Laila bagi kehidupan ekonomi pengrajin batik Desa Ranulogong Kecamatan Randuagung Kabupaten Lumajang (Doctoral dissertation, Universitas Negeri Malang).

Rahardjo, M. (2010). Jenis dan metode penelitian kualitatif. Tersedia secara online di: http://mudjiarahardjo. $\mathrm{com} /$ materi-kuliah/215-jenis-dan-metode-penelitian-kualitatif. html [diakses di Jakarta, Indonesia: 15 Juni 2015]. Rijali, A. (2019). Analisis data kualitatif. Alhadharah: Jurnal Ilmu Dakwah, 17(33), 81-95.

Rijali, A. (2019). Analisis data kualitatif. Alhadharah: Jurnal Ilmu Dakwah, 17(33), 81-95.

Saptyawati, L. (2019). Pemberdayaan ekonomi disabilitas tuna rungu melalui asset based approach menuju kemandirian usaha. In prosiding seminar hasil pengabdian masyarakat (pp. 235-240).

Sukanda, R. (2016). Pemanfaatan Asset Based Community Development Bagi Disabilitas. Pekerjaan Sosial, 15(1).

Surwanti, A. (2014). Model Pemberdayaan Ekonomi Penyandang Disabilitas di Indonesia. Jurnal Manajemen Bisnis, 5(1), 40-58.

Triyono, A. (2014). Pemberdayaan Masyarakat melalui community development program posdaya (pos pemberdayaan keluarga) PT. Holcim Indonesia Tbk Pabrik Cilacap.

Widinarsih, D. (2019). Penyandang disabilitas di indonesia: perkembangan istilah dan definisi. Jurnal Ilmu Kesejahteraan Sosial (Journal of Social Welfare), 20(2). 